\title{
The National Terminology Services: A New Paradigm
}

\author{
Milde Jordaan-Weiss, National Terminology Services \\ Pretoria, South Africa
}

\begin{abstract}
The new dispensation in South Africa necessitated a paradigm shift at the National Terminology Services (NTS). Being part of the Central Government, the NTS has to implement policy as laid down by the government of the day. Former policy, processes and products are described as well as the vision and objectives for the future. The NTS plays a vital role in the implementation of the Reconstruction and Development Program, as no communication is possible without terminology and no development or empowerment can take place without communication. The NTS has the infrastructure and knowledge to facilitate the development of the indigenous South African languages. Problems originating from the implementation of multilingual terminography are discussed, as well as strategies being implemented to overcome them. Finding a new Terminology Management System able to handle the documentation of the 11 official languages has high priority. As the client base of the NTS has broadened with the addition of more official languages, products have to be adapted, changing terminology needs have to be taken into account, and the accessibility of terminology has to be improved. The NTS hopes to contribute towards the promotion of mutual scientific and technical communication in South Africa in this way.
\end{abstract}

Keywords: NATIONAL TERMINOLOGY SERVICES (NTS), MULTILINGUALISM, TERMINOLOGY MANAGEMENT SYSTEM (TMS), BACKGROUND, STRUCTURE, POLICY, TERMINOLOGICAL PROCESSES, PRODUCTS OF TERMINOLOGY, OBJECTIVES, STRATEGIES

Opsomming: Die Nasionale Terminologiediens: 'n nuwe paradigma. Die Nasionale Terminologiediens (NTD) moet as deel van die Sentrale Regering van Suid-Afrika beleid implementeer soos deur die regering bepaal. Daarom moes die NTD noodgedwonge ' $n$ paradigmaskuif ondergaan in ' $n$ nuwe bedeling. Die beleid, prosesse en produkte in die vorige bedeling word bespreek, asook die visie en doelwitte vir die toekoms. Aangesien geen kommunikasie moontlik is sonder terminologie nie, en geen ontwikkeling of bemagtiging sonder kommunikasie kan plaasvind nie, het die NTD ' $n$ onmisbare rol om te speel in die implementering van die Herontwikkeling en Opbouprogram (HOP). Die NTD het die infrastruktuur en kennis om die ontwikkeling van die inheemse Suid-Afrikaanse tale te fasiliteer. Probleme wat ontstaan as gevolg van die implementering van veeltalige terminografie en die strategieë wat geïmplementeer word om dit te oorkom, word bespreek. ' $n$ Nuwe Terminologiebestuurstelsel' (TBS) wat in staat is om die dokumentering van die 11 amptelike tale te hanteer, geniet tans hoë prioriteit. Daar die kliëntebasis van die NTD verbreed het as gevolg die bykomende amptelike tale, moet produkte aangepas word, veranderende terminologiebehoeftes in ag geneem word, en die beskikbaarheid van terminologie verbeter word. Die NTD hoop om op hierdie wyse by te dra tot die bevordering van wedersydse wetenskaplike en tegniese kommunikssie in Suid-Afrika. 
Sleutelwoorde: NASIONALE TERMINOLOGIEDIENS (NID), VEELTALIGHEID, TERMINOLOGIEBESTUURSTELSEL (TBS), AGTERGROND, STRUKTUUR, BELEID, TERMINOLO. GIESE PROSESSE, TERMINOLOGIEPRODUKTE, DOELWITTE, STRATEGIEË

\section{Background}

The National Terminology Services, or NTS for short, is part of the Central Government and is a subdirectorate in the Department of Arts, Culture, Science and Technology. The essential role of the NTS is to facilitate the development of terminology in all the South African languages. It supports government in the formulation, development, implementation and maintenance of national policy and strategies concerning technical languages. In this way it helps to promote mutual scientific and technical communication in all South African communities.

\subsection{Former policy}

Serving the Government of the day means being guided by a Constitution and having to implement policy as laid down by political decision makers. The NTS came into being during the freedom struggle of the Afrikaner, when English was the dominant language in the country. At that stage Government policy called for terminology in Afrikaans, and therefore much attention was given to the development of Afrikaans technical terms. In this process, English concepts and terms were also recorded and systematised.

During the late Eighties, however, the need to include the indigenous African languages in terminology documentation and standardisation became apparent. Due to the restrictions of the then valid constitution, the NTS had no mandate to do this officially, and the staff complement of about 17 terminologists had to concentrate on dictionary projects in English and Afrikaans. On a semi-official level and on request, however, contact with the various Language Boards - our only point of departure at that stage - was established.

Fortunately, the expertise gathered over the years in developing Afrikaans and documenting English terms was not in vain. These collections of terms can serve as a starting point for developing other indigenous languages.

\subsection{Former processes}

Formerly, the processing of terminology from the inception to completion of a project involved assessing the need for a dictionary in a certain field, or complying with the request of a certain body or organisation. Relevant terms (mostly in English) were excerpted from publications and these term lists were 
usually discussed in committee and provided with Afrikaans equivalents and sometimes with definitions. Dictionaries in which the NTS was thus actively involved, were usually printed by the Government Printer.

In other cases, the role of the NTS in dictionary projects was that of co-ordination and providing support services or information in the areas of computerisation, documentation, systematisation and lexicographical methodology.

The processing of terminology at the NTS was computerised in 1984, and for many years the NTS has been involved in the development, standardisation, provision and introduction of a system for the processing of terminology. A database for the documentation of terminology was developed in-house and made available to collaborators free of charge. This database made provision for a large number of information fields or categories on each main entry term. These fields were already in accordance with the standards of the International Organisation for Standardisation (ISO).

Clients of the NTS included language practitioners, subject specialists and individuals and organisations in the field of tertiary education.

\subsection{Former products}

In the past, the emphasis was on comprehensive dictionary projects where the terminologist, assisted by a committee of subject specialists, documented and standardised concepts and terms. Mainly the formal register was accommodated. The resulting products were expensive technical dictionaries aimed at a small market consisting mainly of subject specialists.

\section{Vision and Objectives}

Civil servants are notorious for their resistance to change. Sensing the need for a new perspective, however, the NTS started revising its mission and vision even before the change of government in A pril 1994.

It was clear, even then, that the main change in the language arena would be the increased use of the African languages on an official level, and a resulting shift in the client base of the NTS. Terminology is needed in communication with the State as well as in the workplace and in every facet of everyday life. The NTS therefore has a responsibility in helping to provide the necessary terminologies which are vital for meaningful interaction, thus protecting the language rights of South Africa's citizens.

The NTS also has an important role to play in assisting to improve the scientific and technical communication skills of South African citizens. In order to reach this goal, suitable terminology products have to be delivered. This will benefit all language groups on National, Provincial and Local Government levels. 


\section{Engineering a Paradigm Shift}

One has to admit that the prionities of the present Government differ greatly from what was expected of the Civil Service in the past. This asked for drastic changes - not only in objectives and procedures, but also in mind sets. A total paradigm shift was needed.

\subsection{Guidelines}

At present the main priorities of the Public Sector are contained in the Reconstruction and Development Program (RDP). As terminology is the basis for all technical communication, and no development or empowerment is possible without communication, it can be argued that the NTS, by the very fact of its existence, plays a vital role in the implementation of the RDP.

The promotion of scientific and technical literacy involving the 11 official languages of South Africa lies at the root of all NTS activities. The development of our human resources, which includes training and education, hinges on the quality of communication between trainers and trainees. In this field it is obvious that the NTS has an enormous role to play in supplying these terminologies. Even the objective of meeting the basic needs of the population - as it involves subject fields like housing, water and electricity - should be supported by a supply of relevant terminologies. Economic literacy, involving terminology, is crucial for participation in and stimulation of the country's economy.

According to the Constitution, human rights also include language rights. This means that for all 11 languages, "conditions shall be created for their development and for the promotion of their equal use and enjoyment". This implies multilingualism in its fullest sense.

Multilingual countries are characterised by linguistic inequality in which a dominant language can be used in most areas, whereas minority languages can be used only in some areas. The aim as set out in the Constitution and the RDP is, however, to establish and implement a language policy that encourages and supports financially and otherwise, the utilisation of all the official languages of South Africa.

English, as a language used for wider communication, has an immense advantage over the indigenous South African languages, and care should be taken that this situation does not counteract the goal and promotion of multilingualism in our country. Speakers of Afrikaans worked hard at developing terminologies in that language, and in the process gained a lot of expertise. Now the users of African languages need to do the same. The NTS has the infrastructure and knowledge to facilitate this process and to address community problems regarding terminology. Although the implementation of multilingual terminography presents a great challenge, working with 11 official lan- 
guages instead of 2 poses certain problems, asking for specific strategies to overcome them.

\subsection{Strategies}

\subsubsection{New processes}

A totally new approach to terminology processing is needed, and the new dispensation poses exciting challenges and possibilities. Awaiting a Business Processing Re-engineering, the NTS has in the meantime started gaining the confidence and co-operation of Training Boards and education bodies. These users of terminology are now in a position to provide the NTS with their training material, containing those terms they need in their day to day programs. They may either request definitions or paraphrases in the relevant African language, or equivalents / definitions in any other official South African language.

On the other hand, existing clients, both local and overseas, still have to be catered for, necessitating the standardisation of formats and the provision of networks for the dissemination of terminology. Therefore, finding an effective and user-friendly system for a terminological database has been a high priority at the NTS for the past few months.

\subsubsection{A new Terminology Management System (TMS)}

Creating and managing a terminological database with on-line access for the public has for a long time been a dream of the NTS. After a slow start, this project, called SATERM, is now gaining momentum. Not only did it require a hard look at the existing data and database, but the need for a paradigm shift in this regard became painfully clear as we went along.

As part of a Master Systems Plan for the Department of Arts, Culture, Science and Technology, in-depth research into the needs of terminologists as well as of end-users of the termbank was undertaken. With the help of a consultant, user requirement specifications for a Terminology Management System were compiled. The requirements were rather formidable, but thanks to electronic communication, our quest was brought to the attention of interested parties world-wide. At present, the evaluation of possible systems is far advanced.

Catering for such a broad spectrum of users has its drawbacks. On the one hand we find terminologists and subject specialists with a need for many different data categories. On the other hand teachers, translators or even the man in the street who has access to a PC and modem may want only basic information on specific terms. (On the basis of telephonic queries presently handled, it seems that the main need the public has, is for an equivalent in another lan- 
guage, for spelling and sometimes for a definition.) The pupil or apprentice using SATERM for on-line queries could possibly have a low level of computer literacy, and will need an uncluttered, user-friendly interface. We also have this vision of making full use of multimedia by including voice and video. The former will ensure correct pronunciation in the different languages, while the latter will facilitate the understanding of concepts.

Regarding a TMS, multilingualism also offers a tremendous challenge. As soon as the documentation of the African languages became an important issue, it became apparent that the special characters used in these languages posed a problem as far as the computer was concerned. Although Chinese, Japanese, Hebrew and Arabic fonts are readily available in computer software, developers have yet to make provision for African fonts like the circumflex under the $n, t, d, l$ etc. One well-known program has included the inverted circumflex on the's in its newest version, to be released later this year. Fortunately, the NTS has world-wide contacts in the terminology field, and this problem has already been brought to the attention of various bodies, including the International Organisation for Standardisation (ISO).

The availability of the latest technology to meet the unusual challenges posed by our new society, creates an exciting environment for the NTS to function in. The application of different interfaces for different user levels, generating separate on-line electronic dictionaries from the database, scanning in text by optical character recognition, a multilingual termbank with standardised terms and the possibility of multimedia facilities (graphics and sound), seem to be not too far in the future. With these technological advances in mind, it seems logical to work in the direction of a central data service on the Internet or even the World-Wide Web, combining all existing terminological databases in South Africa. Because such a system will be expensive to develop, it makes sense that the Government should shoulder this responsibility. There will be no cost implications for participating language bureaus, but they will be credited for every query done on their databases.

The possible world-wide interchange of terminology also has to be kept in mind, therefore the system the NTS will go for, has to be able to support the ISO standards for the Terminology Interchange Formats (TIF). This will mean that terminology facilities and products will become available to related information and communication systems.

However, many citizens still lack access to modern technology. Identifying the needs of these clients and presenting terminology to them in an acceptable way is also of great importance.

\subsubsection{Identification of needs}

It follows that the identification of needs, especially in terms of RDP projects, has a high priority. As a Service meant to fulfil the terminological needs of the 
broad South African public, it was crucial to the NTS to ascertain what these needs were. A survey was started in March 1994, and from this certain deductions as to the subject fields and languages needed could be made. Needs assessment, however, will have to be seen as an ongoing process. Keeping in touch with the changing terminology needs of society in a fast changing environment is the only way to keep the work of the NTS relevant. This community based approach also fits in with the Government's policy of democratising State and society. Some time ago Primary Health Care was identified by the Language Boards as one of the areas where there is an urgent need for terms. It is not possible for doctors, nurses and patients to interact if they do not share a common language. Even when the services of an interpreter are used, terminology is needed. Lists of health terms with definitions were compiled and sent to the various Language Boards, who were our only point of contact with the African languages at that stage. From feedback received from the Language Boards, clinics, doctors and nurses, a multilingual publication is presently being compiled. This publication will be widely distributed among health care workers for use and comments.

The NTS is also involved in a trilingual Legal Dictionary (Afrikaans, English and Sepedi). In a legal context, it is of the utmost importance that terminology should be available to citizens in their home languages.

It is possible that other areas like water and electricity supply, building etc. may in the near future be identified as critical regarding terminology.

\subsubsection{New products}

The need for terminology in the African languages is urgent. However, expensive dictionaries which used to take years to compile, are just not feasible in our new society. The illiteracy of marginalised societies implies low technical and economic capacity and addressing this problem brings exciting possibilities to mind. The NTS has committed itself to a quicker turnover with the publication of shorter term lists or dictionaries of basic terms only. Because a lack of generally acceptable terms in the African languages hampers the allocation of equivalents in these languages, draft publications with a request for feed-back are being considered. Inexpensive desktop publications (DTP), meant to reach those with little money for books, are envisaged for the future.

Extension of target groups and a diversity of clients also imply a change in the format and typology of end products. Creative solutions are being developed for multilingual publications, with consideration being given to the use of illustrations where appropriate.

One might even consider breaking away from the traditional printed formats and catering for illiterates by using media based on sound and sight, like radio, tape recordings, pictures and puppet shows. Concerted efforts should perhaps be made to get generally accepted terms to be used in educational TV programs. 
Scientific and technical (or sci-tech) language was previously processed mainly in the formal register. Because of the realisation that scientific and technical communication takes place over a whole spectrum of registers or levels of formality, and because of the variety of literacy levels of the new client groups of the NTS, the more informal registers will receive much more attention in future. The Health Term publication, for example, which will be used at grass roots level in health clinics, will cater for the most basic level of understanding.

\subsubsection{Accessibility}

Improving access to terminology for rural communities gives great scope for creative solutions. Mobile terminology units, community theatre, competitions and flip chart presentations are but a few possibilities. Practical terminology hand-outs at pension day queues, containing information on savings and investments, could be a means of conveying terminology on financial matters to the people who most need it. These might sound like impossible dreams, but if you can dream it, it's possible!

\section{Resources and Structure}

\subsection{Finance}

Extra funds for the expansion of language services are being made available to assist in the modernisation and developing of the indigenous languages, thereby promoting multilingualism.

\subsubsection{National Dictionary Projects}

As language projects and products do not generate money easily, financial aid from the Government is often necessary for both large and small dictionary projects. In the past, the African languages received financial support from the Government by way of funds allocated to the Language Boards and the Department of Education and Training. In addition to this, universities are funders of dictionary projects, e.g. those of isiZulu and isiXhosa.

At present, the Department of Arts, Culture, Science and Technology is conducting a survey to determine where there is a need for financial assistance to national dictionary projects, which as yet receive no official support. Language workers from all 9 African languages received questionnaires on their projects, either current or planned. They were invited to submit business plans for projects covering either the general or the technical vocabulary of the indigenous languages. 
General dictionaries in the vernacular are not part of the mission of the NTS. However, because of our knowledge of lexicographical processes, we were requested to conduct this survey, and our Director will most probably assist in evaluating applications for financial and professional aid. On the strength of the business plans submitted, the Department will establish a basis on which these projects will be subsidised. Projects of this nature will foster self-pride and identity and will also contribute towards nation building.

\subsection{Staff}

Not lacking staff members proficient in Afrikaans and English, appointing terminologists for the various African languages was accorded high priority at the NTS. Although some of the present staff members majored in African languages, mother-tongue speakers are necessary for facilitating the modernisation and development of the indigenous languages. During 1994, permission was granted for the creation of 10 new posts for African terminologists, and appointments will be finalised shortly. More posts will be considered in the foreseeable future. The staff at the NTS is looking forward to this challenge of working with their new colleagues on totally new projects. These new staff members will also be able to satisfy the urgent need for terminology in the education and training fields.

\subsection{New sections}

\subsubsection{Training}

A new section for liaising with Training Boards and other educators has provisionally been formed at the NTS. Two terminologists have been designated to visit education and training organisations to ascertain what their terminological needs are. This section will also be responsible for the training of new terminologists. The basic principles underlying lexicographical and terminographical procedures as applied in the past will be adapted for the African languages.

\subsubsection{Publications and marketing}

A separate section for publications and marketing is also in the pipeline. The NTS has the facilities to handle DTP, and this can be utilised in producing less expensive publications and in increasing turnover. As feedback is expected on these publications, this production procedure makes the speedy revision of publications possible and feasible. 


\section{Commitment}

The NTS is eager in tackling the challenge that we face at the dawning of a democratic society in order to create a system that will allow the equal use and enjoyment of all our languages. This calls for the exploitation of the colourful richness and diversity of this country's languages. Only then will people be able to realise their full potential in our rainbow nation. But the pot of gold at the end of the rainbow can only be reached through industrious effort by all. This includes an adequate supply of terminologies to ensure proper communication. To this end the NTS pledges its resources. 